Received: 12 May 2017

Accepted: 19 September 2018

Published online: 09 October 2018

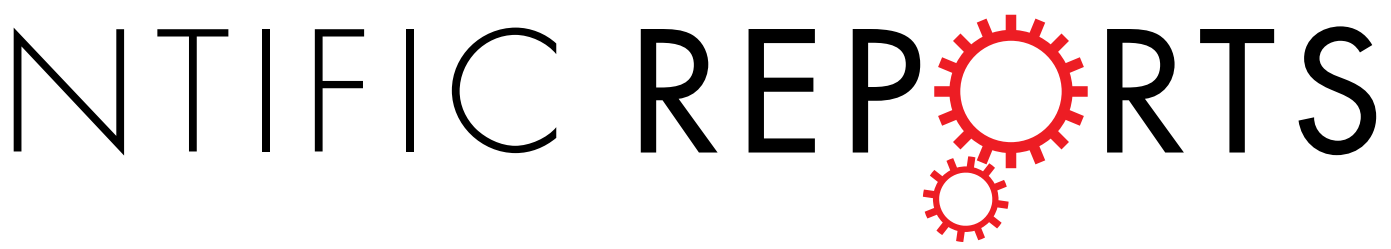

\title{
Microclimate exerts greater control over litter decomposition and enzyme activity than litter quality in an alpine forest-tundra ecotone
}

\author{
Yamei Chen ${ }^{1}$, Yang Liu ${ }^{1,2}$, Jian Zhang ${ }^{1,2}$, Wanqin Yang ${ }^{1,2}$, Runlian $\mathrm{He}^{1}$ \& Changchun Deng ${ }^{1}$
}

Plant litter decomposition is an important biogeochemical process in terrestrial ecosystems. Although climate and substrate quality controls over litter decomposition are reasonably well understood, their impacts on lignocellulose degradation and lignocellulolytic enzymes remain elusive. Here, the decomposition of three leaf litters derived from Salix paraplesia (SP), Deyeuxia scabrescens (DS), and Ajuga ovalifolia (AO), was studied across an alpine forest-tundra ecotone during one snow-covered season with the objective of distinguishing between the effects of microclimate and litter quality on litter decomposition rates and lignocellulolytic enzymes. The results showed that both microclimate and litter quality affected lignocellulose degradation rates and lignocellulolytic enzyme activities; however, microclimate factors had the greater effects. Interestingly, freeze-thaw cycles and moisture were the predominant factors explaining the variations in decomposition rate and enzyme activities. Higher cellulose degradation rates were associated with higher cellulose concentrations. Cellulolytic enzymes had a greater effect on litter decomposition than did ligninolytic enzymes at the early decomposition stage. Litter decomposition and enzyme activities should be given more attention under global climate change, as the direction and magnitude of changes in microclimate factors and litter quality could strongly influence the nutrient cycling and energy fluxes of alpine ecosystems.

Litter decomposition is a key process in carbon (C) and nutrient cycling and is controlled by three main factors: climate, litter quality and decomposing organisms ${ }^{1,2}$. Plant leaf litter can contain considerable amounts of lignin (15-40\%), cellulose and hemicelluloses $(10-50 \%)^{2}$ and polyphenols ${ }^{3}$. In general, the depolymerisation of cellulose is a hydrolytic process involving three classes of cellulolytic (hydrolytic) enzymes: $\beta$-1,4-exoglucanase, endo-1,4- $\beta$-glucanase (EG), and $\beta-1,4$-glucosidase $(\beta G)^{4,5}$. Lignin degradation occurs through oxidative reactions involving a complex set of ligninolytic (oxidative) enzymes, including laccase (Lac), manganese peroxidase $(\mathrm{MnP})$, and lignin peroxidase $(\mathrm{LiP})^{6}$. Extracellular enzymes are directly influenced by temperature and moisture and are released into the environment by microbial secretion and microbial cell lysis ${ }^{7-9}$, which are regulated by litter type $\mathrm{e}^{10,11}$, temperature and moisture ${ }^{12}$.

Climate change can strongly impact abiotic and biotic factors in alpine ecosystems ${ }^{13}$. Average temperatures have increased globally in the last century ${ }^{14,15}$ and have been accompanied by variation in precipitation and snowpack patterns ${ }^{16}$. In the long term, there could be an upward shift of alpine plants, tree line advance ${ }^{17}$, shrub expansion in the alpine zone ${ }^{16,18}$, and graminoid expansion to alpine forb-dominated vegetation ${ }^{19}$. Previous studies have investigated the effects of climate change on litter decomposition and microbial community composition and activity along an elevational gradient, which comprises a suite of highly auto-correlated characteristics (i.e., vegetation, litter, soil microbiology, and snow cover $)^{20-22}$. For example, litter mass loss is affected by litter type and decreases with elevation in the Italian $\mathrm{Alps}^{23}$. In addition, Berger et al. ${ }^{20}$ found that elevation retarded mass loss and associated $\mathrm{C}$ release of beech litter during the first year only and those of decaying pine litter for longer periods in the Austrian Alps. The dehydrogenase activity in alpine and subalpine soils ${ }^{24}$ and the cellulase and xylanase activities in the Austrian Central $\mathrm{Alps}^{25}$ decreased with increasing elevation. Another study reported

${ }^{1}$ Long-term Research Station of Alpine Forest Ecosystems, Institute of Ecology \& Forestry, Sichuan Agricultural University, Chengdu, 611130, China. ${ }^{2}$ Collaborative Innovation Centre of Ecological Security in the Upper Reaches of the Yangtze River, Chengdu, 611130, China. Correspondence and requests for materials should be addressed to Y.L. (email: sicauliuyang@163.com) 
that soil enzymes (i.e., $\beta$-glucosidase, $\mathrm{N}$-acetylglucosaminidase, acid phosphatase, and leucine aminopeptidase) were higher at lower elevations along an elevational gradient from mixed coniferous forest to alpine tundra on Changbai Mountain, China ${ }^{26}$. However, there continues to be a lack of attention paid to the degradation of cellulose, lignin and polyphenols, which are the main macromolecular compounds in leaf litter, or to the lignocellulolytic enzymes ${ }^{27}$.

The alpine forest-tundra ecotone is the transition from coniferous forests to shrublands and alpine meadows ${ }^{28}$, so over short distances along the vegetation gradient, there are differences in microclimate and microbial community composition. Previous studies found substantial litter decomposition in the winter in alpine ecosystems ${ }^{29-32}$ that was attributed to physical destruction caused by freeze-thaw cycles, microbial activity, and hydraulic leaching as well as their integrated effects ${ }^{26}$. Furthermore, mass loss and cellulose and lignin degradation in the litter of some woody plants increased with increasing elevation ${ }^{31}$. However, the decomposition of other litter types (i.e., herb and graminoid litter) and enzyme activities remain to be studied. We hypothesized that 1) microclimate factors exerts greater control over litter decomposition and enzyme activity than does litter quality and 2) cellulolytic enzymes have a greater effect on litter decomposition than do ligninolytic enzymes at the early stage of litter decomposition. To test these hypotheses, litter decomposition and ligninolytic and cellulolytic enzymes were investigated along an elevational gradient (in coniferous forest, treeline and meadow ecosystems) across an alpine forest-tundra ecotone. Three representative types of leaf litter were chosen in this study: Salix paraplesia (SP), a deciduous shrub; Deyeuxia scabrescens (DS), a graminoid species; and Ajuga ovalifolia (AO), a forb species. The initial lignin and cellulose contents were found to differ significantly among these species. Our objective was to distinguish the effects of microclimate and litter quality (i.e., $\mathrm{C}$, nitrogen $(\mathrm{N})$, phosphorus $(\mathrm{P})$, lignin, cellulose and phenols) on the rates of litter decomposition and the activities of ligninolytic and cellulolytic enzymes during one snow-covered season. Whether the activities of ligninolytic and cellulolytic enzymes influence litter decomposition was also evaluated.

\section{Materials and Methods}

Site description. Our study was conducted at Zhegu Mountain, an important riparian river area located at the eastern edge of the Tibetan Plateau in Li County, Sichuan Province, China $\left(31^{\circ} 51^{\prime} 428^{\prime \prime} \mathrm{N}, 102^{\circ} 41^{\prime} 230^{\prime \prime} \mathrm{E}\right)$. The mountain ranges from 3200 to $4800 \mathrm{~m}$ a.s.l. and exhibits remarkable vertical zonality. From the valley to the hilltops, the area is composed of mixed coniferous-broadleaf forest, dark coniferous forest, alpine shrubland, and alpine meadow, with an alpine desert above $4500 \mathrm{~m}$ a.s.l. The alpine tree line, which is located around the upper elevational boundary of the coniferous forest, is approximately $4000 \mathrm{~m}$ a.s.l. The dominant plant species in the coniferous forest are Abies faxoniana and Rhododendron taliense, and the alpine shrubland is dominated by Rosa omeiensis, Berberis silva-taroucana, and others. The dominant herbaceous species of the alpine shrubland include Epilobium angustifolium, Deyeuxia scabrescens, and Gentiana scabra, and the alpine meadow is dominated by Ajuga ovalifolia, Festuca wallichanica, Polygonum paleaceum, Pedicularis roylei, and others. During the winter, there is a period of snow cover of up to 6 to 7 months, from October to April ${ }^{31}$. The soils in the coniferous forest and shrubland and in the alpine meadow are classified as Cambisols and a Histosol (World Reference Base taxonomy). The annual mean temperature and precipitation are approximately $2.9^{\circ} \mathrm{C}$ and $870 \mathrm{~mm}$, respectively, and the relative air humidity and atmospheric pressure are approximately $74 \%$ and $1000 \mathrm{hPa}$.

Experimental design. Three 50-m-wide transects, which were separated by more than $1 \mathrm{~km}$, were set perpendicular to the contour line in the forest-tundra ecotone ${ }^{31}$. Along these three transects, three permanent sample plots $(20 \times 20 \mathrm{~m})$ had been previously established in the coniferous forest $(3900 \mathrm{~m}$ a.s.l.), alpine shrubland (4000 $\mathrm{m}$ a.s.l.), and alpine meadow (4200 m a.s.l.) (Fig. 1). Freshly abscised leaves of SP, DS, and AO were collected in October, when most of the litter fall occurs. After the removal of contaminating debris, the leaf litter was oven-dried at $65^{\circ} \mathrm{C}$ for $48 \mathrm{~h}$ and mixed to provide a homogeneous sample. Portions of $10.00 \mathrm{~g}$ of leaf material were enclosed in nylon net bags $(20 \times 20 \mathrm{~cm}$, surface-layer mesh of $1.0 \mathrm{~mm}$ and ground-layer mesh of $0.5 \mathrm{~mm})$. Three bags for each species were used to determine the initial litter quality, and 54 litterbags (three vegetation types $\times$ three plots $\times$ three species $\times$ two litterbags) were prepared for the study (Fig. 1). Litterbags of each species were placed on top of the litter layer in sample plots in the coniferous forest, tree line, and alpine meadow on 30 October 2012, and the litterbags were placed at least $5 \mathrm{~cm}$ apart. The temperatures during litter decomposition were automatically monitored every $3 \mathrm{~h}$ using thermometers (iButton DS1921-F5, Maxim/Dallas Semiconductor, Sunnyvale, CA, USA) in the litterbags. The snow cover thickness was manually monitored every month. Six bags of each litter type were collected from each plot on 30 April 2013. Three were cleaned to measure the litter mass loss and litter quality, and the other three bags were used to determine the enzyme activity and moisture content. A subsample (approximately $60 \%$ of fresh weight) of litter from each bag was stored at $4^{\circ} \mathrm{C}$ for enzyme extraction, and the remaining litter in the three bags was oven-dried at $65^{\circ} \mathrm{C}$ to measure the moisture content.

Chemical analyses. The $\mathrm{C}, \mathrm{N}$ and $\mathrm{P}$ concentrations were determined as described by $\mathrm{Lu}^{33}$. The $\mathrm{C}$ concentration was determined using the dichromate oxidation-sulphate-ferrous titration method, in which $0.2000 \mathrm{~g}$ of the sub-samples were acid-digested with a solution of $8 \mathrm{~mL}$ of $\mathrm{H}_{2} \mathrm{SO}_{4}(98 \%)$ and $3 \mathrm{~mL}$ of $\mathrm{H}_{2} \mathrm{O}_{2}$ at $190^{\circ} \mathrm{C}$ for $30 \mathrm{~min}$. The digested solution was then transferred to a $100-\mathrm{mL}$ volumetric flask, quantified, filtered, and stored to measure the $\mathrm{N}$ and $\mathrm{P}$ concentration $\mathrm{s}^{30}$, which were determined by the Kjeldahl method and molybdenum blue colorimetry, respectively.

The lignin and cellulose concentrations were determined using the acid detergent-lignin method ${ }^{34}$, with some modifications by He et al. ${ }^{35}$. One g of oven-dried and ground sub-samples was transferred to digestion tubes and suspended in a solution of $\mathrm{H}_{2} \mathrm{SO}_{4}(1.0 \mathrm{M})$ and cetyltrimethylammonium bromide (CTAB; $\left.20 \mathrm{~g} \mathrm{~L}-1 ; 80 \mathrm{~mL}\right)$. The tubes were heated at $169^{\circ} \mathrm{C}$ for $1 \mathrm{~h}$, and after cooling, they were transferred to a sand core funnel $(50 \mathrm{~mL}, \mathrm{G} 3$ specification) and washed with acetone until the solution obtained through the suction filtration was clean. After 


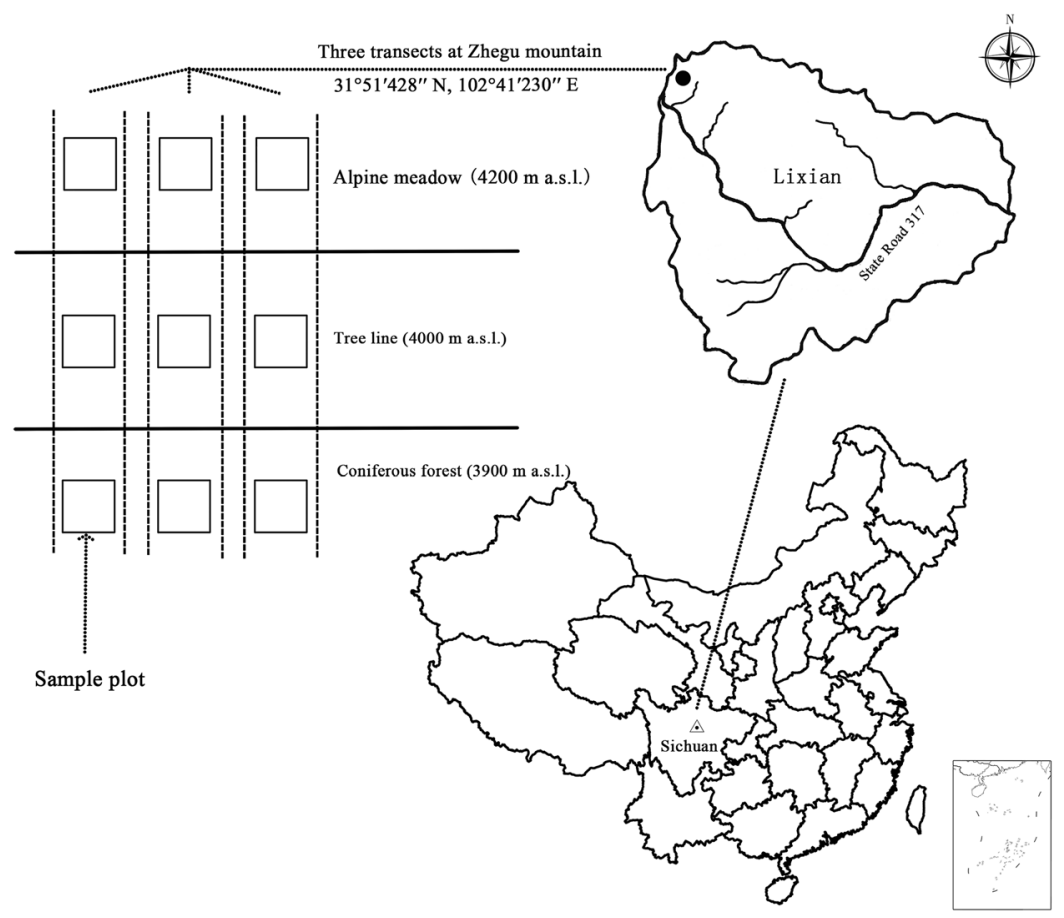

Figure 1. Diagram of the experimental layout of litterbags in the selected permanent sample plots across an alpine forest-tundra ecotone on the eastern Tibetan Plateau. The map of study area in China was generated with ARCGIS (version 10.2, ESRI, Redlands, CA, USA, http://desktop.arcgis.com/en/arcmap). The map and the diagram of the sample plots were assembled using PHOTOSHOP software (version 6.0; Adobe Systems, Mountain View, CA, https://www.adobe.com).

oven drying at $170^{\circ} \mathrm{C}$ for $1 \mathrm{~h}$, the sample and tube were weighed together and designated W1. The sample was subsequently soaked for more than $3 \mathrm{~h}$ in an $\mathrm{H}_{2} \mathrm{SO}_{4}$ solution (72\%), subjected to suction filtration and washed with acetone, as described above. The sample was then oven-dried at $170^{\circ} \mathrm{C}$ for $1 \mathrm{~h}$. The sample and tube were weighed together and designated W2, and both were then placed in a muffle furnace (Box Furnace; Lindberg/ Blue M, Asheville, NC, USA) at $550^{\circ} \mathrm{C}$ for $3 \mathrm{~h}$ and weighed after cooling (designated as W3). The cellulose and lignin concentrations $\left(\mathrm{g} \cdot \mathrm{kg}^{-1}\right)$ were calculated as follows:

$$
\begin{aligned}
& \text { Cellulose concentration }=1000 \times(\mathrm{W} 1-\mathrm{W} 2) \\
& \text { Lignin concentration }=1000 \times(\mathrm{W} 2-\mathrm{W} 3)
\end{aligned}
$$

Based on the oxidation-reduction principle, the total phenol concentration was determined using the FolinCiocalteu method ${ }^{36}$.

Enzyme extraction and assays. Enzymes were extracted according to the methods described by Criquet et al. ${ }^{37}$ with minor modifications. First, 4 to $9 \mathrm{~g}$ of freshly powdered litter $(<0.5 \mathrm{~mm})$ were extracted overnight in $15 \mathrm{~mL}$ of $0.1 \mathrm{M} \mathrm{CaCl}_{2}$ solution with $0.05 \%$ Tween 80 and $0.40 \mathrm{~g}$ of polyvinylpolypyrrolidone at $4^{\circ} \mathrm{C}$. The suspension was centrifuged at $12,000 \times \mathrm{g}$ and $4^{\circ} \mathrm{C}$ for $20 \mathrm{~min}$, and the supernatant was subsequently dialysed for $48 \mathrm{~h}$ at $4^{\circ} \mathrm{C}$ in $14-\mathrm{kDa}$ molecular mass cut-off cellulose dialysis tubing against frequently exchanged $2 \mathrm{mM}$ bis-Tris(bis[2-hydroxyethyl]imino-tris[hydroxymethyl] methane) buffer, $\mathrm{pH}$ 6.0. Extracts that had been boiled for 15 min served as controls for enzyme activity, except $\mathrm{MnP}$ activity for which the reaction mixture without $\mathrm{Mn}$ served as a control. Units of enzyme activities are calculated based on the mass of remaining $\mathrm{C}$ and expressed as nmol $\min ^{-1}$ per g of C.

Unless otherwise indicated, all enzyme activities described below were analysed at the optimal $\mathrm{pH}$ value and temperature. Activity assay reaction mixtures of $\mathrm{Lac}, \mathrm{MnP}$, and $\mathrm{LiP}$ were allowed to proceed for $5 \mathrm{~min}$ at $30^{\circ} \mathrm{C}^{38}$. Using syringaldazine as a substrate, Lac activity was measured according to the methods described by Criquet et al. ${ }^{37}$. The reaction mixture contained $2.5 \mathrm{~mL}$ of $0.1 \mathrm{M}$ phosphate buffer $(\mathrm{pH} 5.7)$ and $0.1 \mathrm{~mL}$ of $5 \mathrm{mM}$ syringaldazine solution. The rate of oxidation of syringaldazine to quinone was measured at $525 \mathrm{~nm}\left(\varepsilon=65000 \mathrm{M}^{-1}\right.$ $\left.\mathrm{cm}^{-1}\right)$.

The MnP activity was measured according to the methods developed by Arora et al. ${ }^{39}$ and Fujii et al. ${ }^{38}$. Using phenol red as a substrate, the reaction mixture contained $2.0 \mathrm{~mL}$ of a sodium succinate buffer $(50 \mathrm{mM})(\mathrm{pH}$ 4.5), $2.0 \mathrm{~mL}$ of sodium lactate $(50 \mathrm{mM}), 0.8 \mathrm{~mL}$ of $\mathrm{Mn}$ sulphate $(0.1 \mathrm{mM})$ (or an equimolar amount of EDTA for the control), $1.4 \mathrm{~mL}$ of phenol red $(0.1 \mathrm{mM}), 0.8 \mathrm{~mL}$ of $\mathrm{H}_{2} \mathrm{O}_{2}(50 \mathrm{mM}), 2.0 \mathrm{~mL}$ of albumin $(0.1 \%)$, and $1.0 \mathrm{~mL}$ of enzyme extract, and the reaction was initiated by adding $\mathrm{H}_{2} \mathrm{O}_{2}$. A $2-\mathrm{mL}$ aliquot of the reaction mixture 
was removed and added to $40 \mathrm{~mL}$ of $5 \mathrm{M} \mathrm{NaOH}$. The oxidation rate of phenol red was measured at $610 \mathrm{~nm}$ $\left(\varepsilon=4460 \mathrm{M}^{-1} \mathrm{~cm}^{-1}\right)$.

The LiP activity was measured according to the methods described by Arora et al. ${ }^{39}$ and Fujii et al. ${ }^{38}$. Using Azure $\mathrm{B}$ as the substrate, the reaction mixture contained $0.5 \mathrm{~mL}$ of a sodium tartrate buffer $(50 \mathrm{mM})(\mathrm{pH} 3.0)$, $0.5 \mathrm{~mL}$ of Azure B $(32 \mathrm{mM}), 0.5 \mathrm{~mL}$ of $\mathrm{H}_{2} \mathrm{O}_{2}(100 \mathrm{mM})$, and $0.5 \mathrm{~mL}$ of enzyme extract, and the reaction was initiated by adding $\mathrm{H}_{2} \mathrm{O}_{2}$. The oxidation rate of Azure $\mathrm{B}$ was measured at $651 \mathrm{~nm}\left(\varepsilon=48800 \mathrm{M}^{-1} \mathrm{~cm}^{-1}\right)$.

The EG activity was determined by measuring the release of reducing sugars from appropriate substrates. The EG activity was measured according to methods described by Criquet ${ }^{40}$. The reaction mixture, which contained $0.2 \mathrm{~mL}$ of enzyme extract and $0.6 \mathrm{~mL}$ of $50 \mathrm{mM}$ sodium acetate buffer ( $\mathrm{pH} 6.0$ ) containing $2 \%$ carboxymethylcellulose, was incubated for $1 \mathrm{~h}$ at $50^{\circ} \mathrm{C}$.

The $\beta$ G activity was measured according to the methods described by Valášková $e t$ al. ${ }^{41}$. The reaction mixture contained $0.16 \mathrm{~mL}$ of $1.2 \mathrm{mM}$ p-nitrophenyl- $\beta$-D-glucoside in $50 \mathrm{mM}$ sodium acetate buffer ( $\mathrm{pH} 5.0$ ) and $0.04 \mathrm{~mL}$ of enzyme extract. The reaction mixtures were incubated at $40^{\circ} \mathrm{C}$ for $40 \mathrm{~min}$. The reaction was stopped by the addition of $0.1 \mathrm{~mL}$ of $0.5 \mathrm{M}$ sodium carbonate, and the absorbance was read at $400 \mathrm{~nm}$. The enzyme activity was calculated using the molar extinction coefficient of $p$-nitrophenol $\left(11,600 \mathrm{M}^{-1} \mathrm{~cm}^{-1}\right)$.

Using birchwood xylan as the substrate ${ }^{42}$, the EX activity was measured by incubating $0.2 \mathrm{~mL}$ of the enzyme extract with $0.6 \mathrm{~mL}$ of $50 \mathrm{mM}$ sodium acetate buffer ( $\mathrm{pH}$ 6.0) containing $2 \%$ birchwood xylan for $1 \mathrm{~h}$ at $50^{\circ} \mathrm{C}$. The amount of reducing sugars was determined using the dinitrosalicylic acid method ${ }^{43}$.

Calculations and statistics. Calculations of litter dry mass loss $(L)$, and the release $\left(R_{i}\right)$ of C, cellulose, lignin and total phenol at the end of the snow-covered season were performed as follows:

$$
\begin{gathered}
L=100 \times \frac{\left(\mathrm{M}_{0}-\mathrm{M}_{\mathrm{i}}\right)}{\mathrm{M}_{0}} \\
R i(\%)=100 \times \frac{\left(\mathrm{M}_{0} \mathrm{C}_{0}-\mathrm{M}_{\mathrm{i}} \mathrm{C}_{\mathrm{i}}\right)}{\mathrm{M}_{0} \mathrm{C}_{0}}
\end{gathered}
$$

where $\mathrm{M}_{0}$ and $\mathrm{M}_{\mathrm{i}}$ are the dry masses of the initial and remaining litter in the litterbags, respectively, and $\mathrm{C}_{0}$ and $\mathrm{C}_{\mathrm{i}}$ are the concentration $\left(\mathrm{g} \cdot \mathrm{kg}^{-1}\right.$ ) of $\mathrm{C}$, cellulose, lignin and total phenol in the initial and remaining litter, respectively. To characterise the temperature parameters, we calculated the average temperature (AT), frequency of the freeze-thaw cycle (FFTC), positive accumulated temperature (PAT) and negative accumulated temperature (NAT) from the monitored temperature data ${ }^{44}$. The FFTC was calculated using the following definitions: a decrease to a temperature below $0^{\circ} \mathrm{C}$ for at least $3 \mathrm{~h}$ followed by an increase to a temperature above $0^{\circ} \mathrm{C}$ for at least $3 \mathrm{~h}$ or an increase to a temperature above $0^{\circ} \mathrm{C}$ for at least $3 \mathrm{~h}$ followed by a decrease to a temperature below $0^{\circ} \mathrm{C}$ for at least $3 \mathrm{~h}^{45}$. Moreover, the PAT and NAT were calculated as the sum of the average daily temperatures above/below $0{ }^{\circ} \mathrm{C}$ during the decomposition stage, respectively. The average thickness of the snow cover (ATSC) in different vegetation types was also calculated.

First, a two-way analysis of variance (ANOVA) was used to evaluate the effects of vegetation type, litter type, and their interaction on overall litter decomposition and enzyme activities in the litter. We also used non-metric multidimensional scaling (NMDS) with Bray-Curtis distance analysis to visualise the effects of vegetation type and litter type on overall litter decomposition and enzyme activities in the litter. One-way ANOVAs were conducted for initial litter quality. In all cases, more than two groups were examined, and least significant difference (LSD) tests were conducted to compare the associated group means. We performed a redundancy analysis (RDA) to determine which initial litter quality and environmental factors were related to the overall litter decomposition and enzyme activities and to determine the effect of enzyme activities on litter decomposition. When we conducted Monte Carlo permutation $(\mathrm{n}=499)$, the "Summarise Effects of Expl. Variables" method was used to first individually determine the effect of each variable on the dependent variable and then to find the forces (independent variable) driving the dependent variable by adding new variables based on the order of explanation. We used variation partitioning analysis (VPA) to a) compare the effects of litter quality and environmental factors on litter decomposition and ligninolytic and cellulolytic enzyme activities and b) compare the effects of ligninolytic enzymes and cellulolytic enzyme activities on litter decomposition. Two-way ANOVAs, one-way ANOVAs and LSD tests were performed using SPSS Statistics for Windows (version 21.0). NMDS was performed with the vegan package in R software for Windows (version R 3.0.1), and RDA and VPA were performed using CANONCO software for Windows (version 5. 0).

\section{Results}

Microclimatic factors and initial litter quality. The average daily temperature fluctuation was greater at the tree line and in the alpine meadow than in the coniferous forest, as shown in Fig. 2. The AT and PAT in winter for litter decomposition decreased across elevations at the alpine forest-tundra ecotone in the order tree line $>$ alpine meadow $>$ coniferous forest (Table 1). The ATSC decreased in the order coniferous forest $(7.2 \mathrm{~cm})>$ tree line $(6.4 \mathrm{~cm})>$ alpine meadow $(1.1 \mathrm{~cm})$, and the frequency of the freeze-thaw cycle $($ FFTC) was highest in the alpine meadow (327) followed by at the tree line (270) and in the coniferous forest (135) (Table 1). The average moisture content of the leaf litter was highest in the coniferous forest followed by in the alpine meadow and at the tree line (Table 1). The initial litter $\mathrm{C}$ concentration, $\mathrm{P}$ concentration and lignin concentration of SP were higher than those of DS and AO, and the lignin:N ratio of SP (9.24) was higher than that of DS (4.88). The initial litter total phenol and cellulose concentrations of DS were lower than those of SP and higher than those of AO (Table 2). 


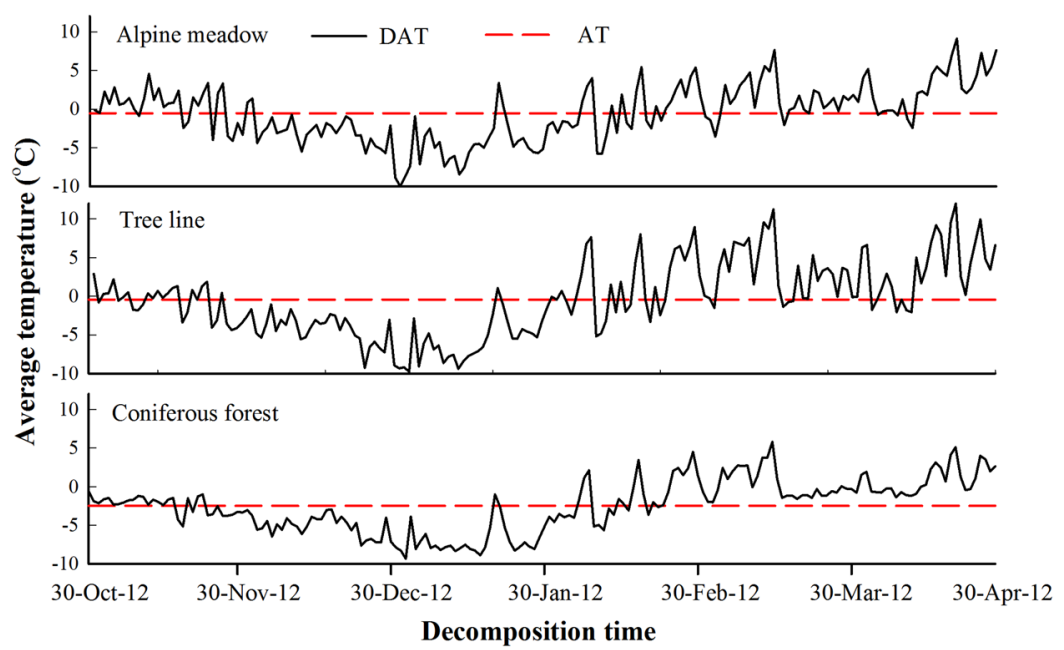

Figure 2. Dynamics of the average temperature in ambient leaf litter in the coniferous forest, at the tree line and in the meadow of the alpine forest-tundra ecotone from 30 October 2012 to 30 April 2013. DAT: daily average temperature; AT: average temperature.

\begin{tabular}{|l|l|l|l|l|l|l|}
\hline Vegetation type & AT $\left({ }^{\circ} \mathbf{C}\right)$ & FFTC (times) & PAT $\left({ }^{\circ} \mathbf{C}\right)$ & NAT $\left({ }^{\circ} \mathbf{C}\right)$ & $\begin{array}{l}\text { ATSC } \\
(\mathbf{c m})\end{array}$ & AMC (\%) \\
\hline Coniferous forest & -2.5 & 135 & 86.5 & -541.1 & 7.2 & 71.3 \\
\hline Tree line & -0.4 & 270 & 312.7 & -393.1 & 6.4 & 26.4 \\
\hline Alpine meadow & -0.5 & 327 & 223.4 & -323.1 & 1.1 & 37.0 \\
\hline
\end{tabular}

Table 1. Temperature parameters, average thickness of the snow cover and average moisture content of leaf litter undergoing decomposition during the snow-covered season in the coniferous forest, at the tree line, and in meadow sites in the alpine forest-tundra ecotone. AT, average temperature; FFTC, frequency of the freezethaw cycle; PAT, positive accumulated temperature; NAT, negative accumulated temperature; ATSC, average thickness of the snow cover; AMC, average moisture content.

Mass loss and element release. After a winter of decomposition, the mass loss and C release of SP were higher in the coniferous forest than in the alpine meadow and at the tree line, whereas the mass loss and $\mathrm{C}$ release of DS did not vary significantly with elevation (Fig. 3A and B). The cellulose degradation of SP and AO in the alpine meadow $(-90 \%$ and $14 \%)$ was lower than that in the coniferous forest $(-15 \%$ and $29 \%)$ or tree line $(-14 \%$ and $30 \%$ ), and the cellulose degradation of DS and AO was much higher than that of SP (Fig. 3C). In contrast, the lignin degradation of the three species in the coniferous forest $(-5 \%$ to $-97 \%)$ was much lower than that in the tree line ( $-2 \%$ to $43 \%)$ or alpine meadow (15\% to $46 \%)$ (Fig. 3D). The total phenol loss of the three species was almost two times higher in the coniferous forest than in the tree line or alpine meadow (Fig. 3E).

Ligninolytic and cellulolytic enzyme activities. The Lac activities of SP and DS were higher at the tree line than in the coniferous forest and alpine meadow. The Lac activity of $\mathrm{AO}$ and the MnP activity of the three species decreased from the coniferous forest to the alpine meadow (Fig. 4A,B), and the MnP activity of SP at the tree line and in the alpine meadow was approximately 3 times higher than that of each of DS and AO (Fig. 4B). The LiP activity of AO was higher than that in SP and DS in the coniferous forest and at the tree line (Fig. 4C). Overall, the EG, $\beta \mathrm{G}$, and EX activities were higher in the coniferous forest than at the tree line or in the alpine meadow, and the EG, $\beta$ G and EX activities of DS were at least twice as high as those of SP and AO except for $\beta G$ activity in the coniferous forest (Fig. 4D-F).

Effects of vegetation type and litter type on mass loss, element release and enzyme activities. The two-way ANOVA and NMDS analysis revealed that vegetation type and litter type had significant effects on mass loss $(\mathrm{P}<0.05)$, element release $(\mathrm{P}<0.01)$ and enzyme activities $(\mathrm{P}<0.05)$ but not on $\mathrm{C}$ release $(\mathrm{P}=0.095)$ or $\mathrm{MnP}(\mathrm{P}=0.733)$ (Table 3; Fig. 5). The RDA showed that $41 \%$ of the variation in overall litter decomposition was explained by axis 1 , which was mainly related to microclimatic factors, and that $29 \%$ of the variation was explained by axis 2 , which was mainly related to litter quality. Furthermore, the explanatory power of microclimatic factors $(53 \%)$ was higher than that of litter quality $(28 \%)$ in terms of explaining the variation in overall litter decomposition. Among the litter quality and microclimatic variables, FFTC (30\%) was the strongest explanatory factor, and mass loss, lignin degradation and total phenol loss were mainly controlled by FFTC, moisture content and ATSC. The release of $\mathrm{C}$ and cellulose degradation, which were mainly related to axis 2 , were mainly controlled by the concentration of cellulose and C/P (Fig. 6A and Table 4). 


\begin{tabular}{|l|l|l|l|l|l|l|l|l|l|}
\hline $\begin{array}{l}\text { Litter } \\
\text { type }\end{array}$ & $\mathbf{C}\left(\mathbf{g} \cdot \mathbf{k g}^{-1}\right)$ & $\mathbf{N}\left(\mathbf{g} \cdot \mathbf{k g}^{-1}\right)$ & $\mathbf{P}\left(\mathbf{g} \cdot \mathbf{k g}^{-1}\right)$ & $\mathbf{C} / \mathbf{N}$ & $\mathbf{C} / \mathbf{P}$ & ${\text { Cellulose }\left(\mathbf{g}^{-1} \mathbf{k g}^{-1}\right)}$ & Lignin $_{\left(\mathbf{g} \cdot \mathbf{k g}^{-1}\right)}$ & Lignin/N $^{\text {Tign }}$ & TPh $\left(\mathbf{g} \cdot \mathbf{k g}^{-1}\right)$ \\
\hline SP & $488.60(13.80)^{\mathrm{a}}$ & $18.6(1.18)^{\mathrm{a}}$ & $3.77(0.05)^{\mathrm{a}}$ & $26.34(1.85)^{\mathrm{a}}$ & $129.65(4.02)^{\mathrm{c}}$ & $75.07(28.53)^{\mathrm{c}}$ & $171.20(50.37)^{\mathrm{a}}$ & $9.24(2.74)^{\mathrm{a}}$ & $23.50(0.13)^{\mathrm{a}}$ \\
\hline DS & $451.07(16.21)^{\mathrm{b}}$ & $12.95(0.10)^{\mathrm{a}}$ & $1.55(0.01)^{\mathrm{b}}$ & $34.85(1.52)^{\mathrm{a}}$ & $290.58(12.70)^{\mathrm{b}}$ & $285.18(10.34)^{\mathrm{a}}$ & $3.10(6.20)^{\mathrm{b}}$ & $4.88(0.51)^{\mathrm{b}}$ & $12.88(0.53)^{\mathrm{b}}$ \\
\hline AO & $409.36(2.87)^{\mathrm{c}}$ & $13.47(4.73)^{\mathrm{a}}$ & $1.14(0.04)^{\mathrm{c}}$ & $32.63(9.57)^{\mathrm{a}}$ & $360.81(14.71)^{\mathrm{a}}$ & $186.30(11.52)^{\mathrm{b}}$ & $73.41(0.95)^{\mathrm{b}}$ & $5.84(1.67)^{\mathrm{ab}}$ & $22.51(0.89)^{\mathrm{a}}$ \\
\hline
\end{tabular}

Table 2. Initial quality of Salix paraplesia (SP), Deyeuxia scabrescens (DS), and Ajuga ovalifolia (AO) leaf litters (means $\pm \mathrm{SD}, \mathrm{n}=3$ ). C, carbon concentration; $\mathrm{N}$, nitrogen concentration; $\mathrm{P}$, phosphorus concentration; $\mathrm{TPh}$, total phenol concentration. Different lowercase letters indicate significant differences $(\mathrm{P}<0.05)$ in the same variable among different species.
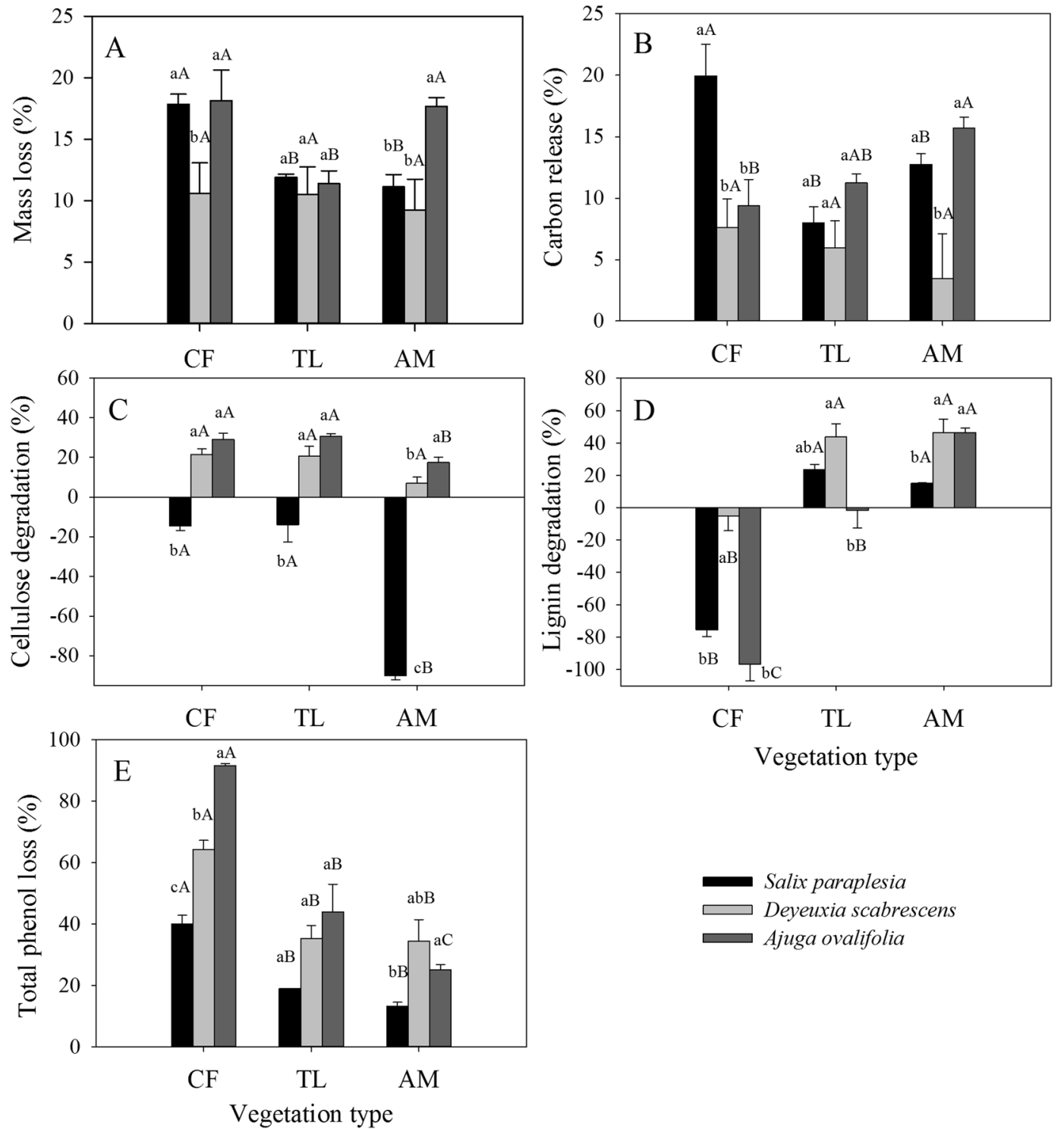

Figure 3. Mass loss and element release (\%) of Salix paraplesia (SP), Deyeuxia scabrescens (DS), and Ajuga ovalifolia (AO) leaf litter. AM, alpine meadow; TL, tree line; $\mathrm{CF}$, coniferous forest. Different lowercase letters indicate significant differences $(\mathrm{P}<0.05)$ among different litter types within the same vegetation type, and different uppercase letters indicate significant differences $(\mathrm{P}<0.05)$ among vegetation types within the same litter type. The data are the means \pm SE $(n=3)$.

Axes 1 and 2 explained $46 \%$ and 16\%, respectively, of the variation in enzyme activities, and microclimatic factors explained more of the variation (48\%) than did litter quality (17\%). Moisture content (34\%) was the strongest explanatory factor, and the total phenol, cellulose and lignin concentrations were significant explanatory factors related to litter quality (Fig. $6 \mathrm{~B}$ and Table 5). The $\beta \mathrm{G}$, EG and EX enzyme activities were positively 

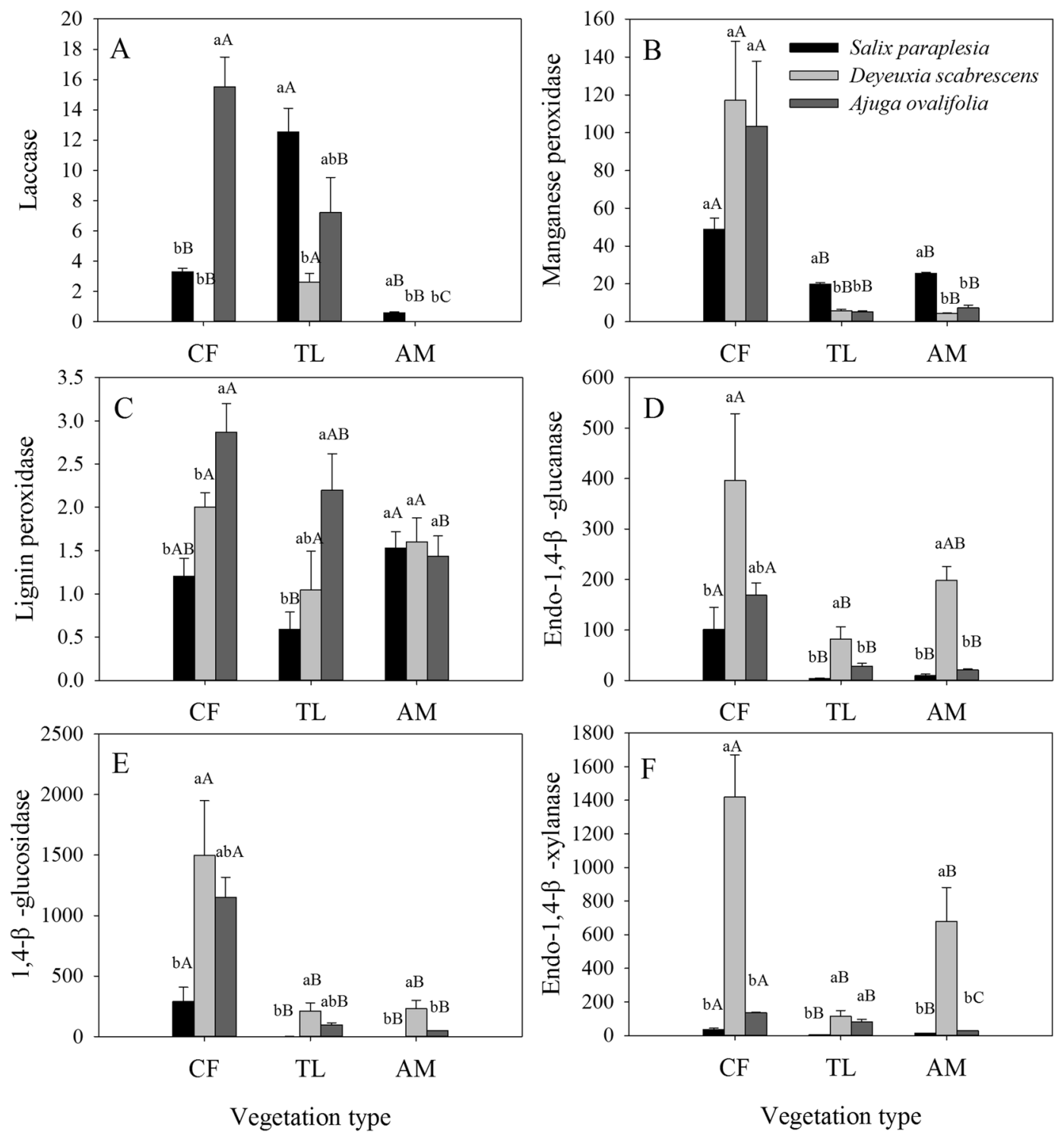

Figure 4. Ligninolytic and cellulolytic enzyme activities (nmol $\mathrm{min}^{-1}$ per g C) of Salix paraplesia (SP), Deyeuxia scabrescens (DS), and Ajuga ovalifolia (AO) leaf litter. AM, alpine meadow; TL, tree line; CF, coniferous forest. Different lowercase letters indicate significant differences $(\mathrm{P}<0.05)$ among different litter types within the same vegetation type, and different uppercase letters indicate significant differences $(\mathrm{P}<0.05)$ among vegetation types within the same litter type. The data are the means $\pm S E(n=3)$.

related to cellulose concentration (Fig. 6B), and the total phenol concentration was positively related to Lac and $\mathrm{LiP}$ activities and negatively related to EG and EX activities.

Effects of enzyme activities on litter mass loss and element release. The RDA showed that the variation in litter mass loss and element release could be affected by enzyme activities. The explanatory power of cellulolytic enzyme activities (48\%) was higher than that of ligninolytic enzyme activities (29\%) in terms of the variation in litter mass loss and element release. Among the enzyme variables, $\beta G$ activity $(27 \%)$ was the strongest explanatory factor (Fig. 6C and Table 6).

\section{Discussion}

The findings of the present study demonstrated that both microclimate and litter quality had significant effects on overall litter decomposition. Moreover, microclimatic factors played a more important role than did litter quality in explaining the variation in overall litter decomposition at the early decomposition stage. Margesin et al. ${ }^{23}$ found that the decomposition of pine needle litter was lower at higher-elevation sites than at lower-elevation sites, whereas no consistent trend of mass loss of the three litter types along the ecotone was detected in the present study. Drewnik ${ }^{46}$ found that cellulose degradation decreased with elevation within a given vegetation zone in a montane-alpine ecotone, which is consistent with our results that lower cellulose degradation in SP and AO litter 


\begin{tabular}{|c|c|c|c|c|c|c|}
\hline \multirow[b]{2}{*}{ Factors } & \multicolumn{2}{|c|}{$\begin{array}{l}\text { Vegetation type } \\
(\mathrm{df}=2)\end{array}$} & \multicolumn{2}{|c|}{ Litter type $(\mathrm{df}=2)$} & \multicolumn{2}{|c|}{$\begin{array}{l}\text { Vegetation type } \times \text { litter } \\
\text { type }(\mathrm{df}=4)\end{array}$} \\
\hline & F value & P value & F value & Pvalue & F value & P value \\
\hline Mass loss (\%) & 4.726 & $<0.050$ & 8.030 & $<0.010$ & 2.357 & 0.092 \\
\hline Carbon release (\%) & 2.697 & 0.095 & 12.311 & $<0.001$ & 4.603 & $<0.050$ \\
\hline Cellulose degradation (\%) & 71.223 & $<0.001$ & 229.126 & $<0.001$ & 26.57 & $<0.001$ \\
\hline Lignin degradation (\%) & 149.242 & $<0.001$ & 35.498 & $<0.001$ & 11.911 & $<0.001$ \\
\hline Total phenol loss (\%) & 74.491 & $<0.001$ & 36.285 & $<0.001$ & 6.667 & $<0.010$ \\
\hline Laccase & 34.054 & $<0.001$ & 26.397 & $<0.001$ & 21.043 & $<0.001$ \\
\hline Manganese peroxidase & 25.263 & $<0.001$ & 0.383 & 0.687 & 2.907 & 0.051 \\
\hline Lignin peroxidase & 5.158 & $<0.050$ & 10.096 & $<0.010$ & 3.218 & $<0.050$ \\
\hline Endo-1,4- $\beta$-glucanase & 11.763 & $<0.010$ & 12.375 & $<0.001$ & 1.428 & 0.265 \\
\hline $1,4-\beta$-glucosidase & 27.403 & $<0.001$ & 8.092 & $<0.010$ & 3.198 & $<0.050$ \\
\hline Endo-1,4- $\beta$-xylanase & 13.892 & $<0.001$ & 40.325 & $<0.001$ & 11.279 & $<0.001$ \\
\hline
\end{tabular}

Table 3. Effects of vegetation type, litter type, and their interactions on mass loss, element release and enzyme activities of leaf litter.
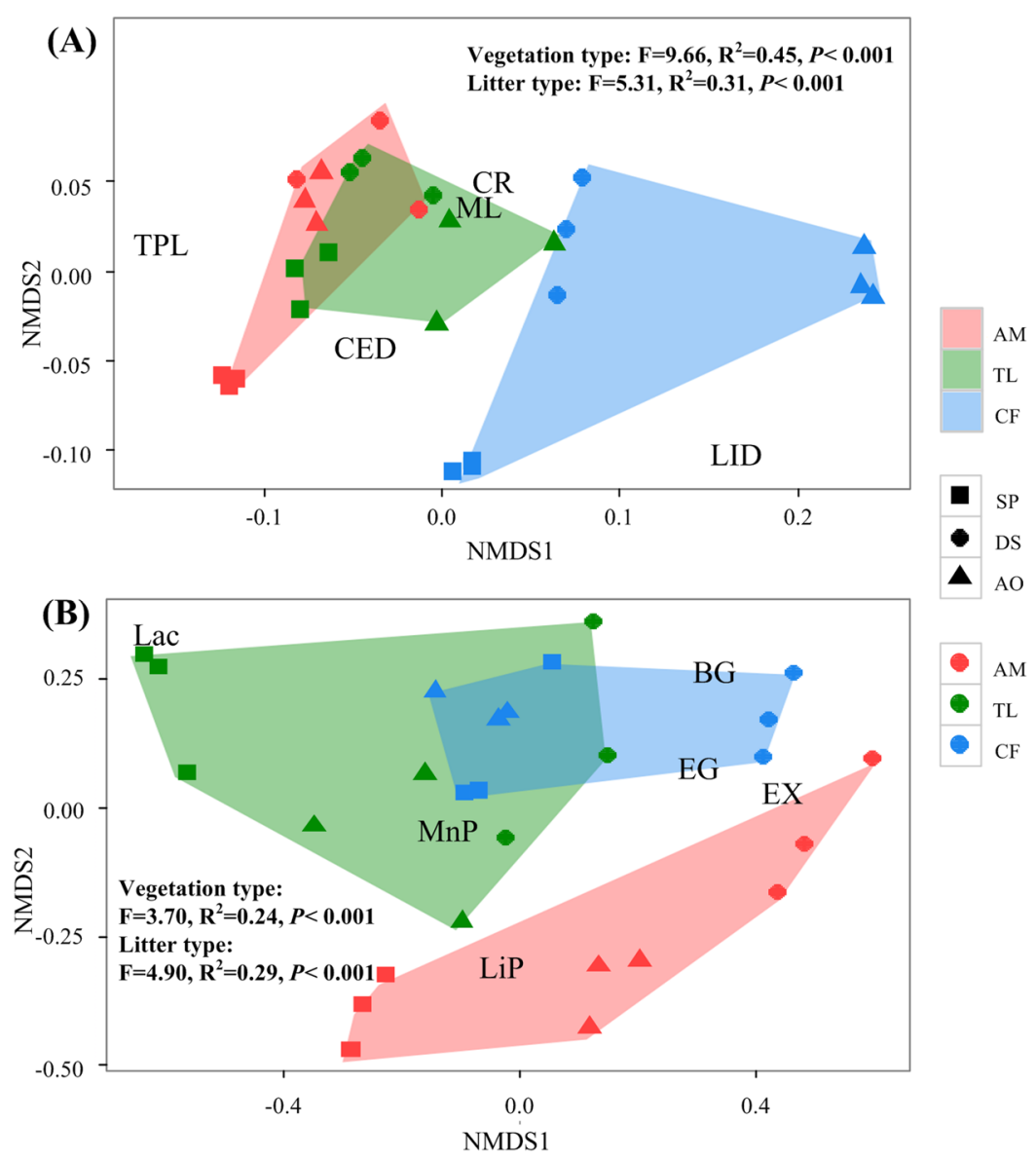

Figure 5. Non-metric multidimensional scaling (NMDS) with Bray-Curtis distance analysis of mass loss, element release (\%) (A) and enzyme activities (B) of leaf litters. NMDS1 shows the effect of vegetation type, and NMDS2 shows the effect of litter type. AM, alpine meadow; TL, tree line; CF, coniferous forest; SP, Salix paraplesia; DS, Deyeuxia scabrescens; AO, Ajuga ovalifolia; ML, mass loss (\%); CR, carbon release (\%); CED, cellulose degradation (\%); LID, lignin degradation (\%); TPL, total phenol loss (\%); Lac, laccase; MnP, manganese peroxidase; LiP, lignin peroxidase; EG, endo-1,4- $\beta$-glucanase; $\beta \mathrm{G}, 1,4$ - $\beta$-glucosidase; EX, endo-1,4- $\beta$-xylanase.

was observed at higher elevation. During the snow-covered season, the snowpack gradient generates heterogeneity in temperature and moisture ${ }^{47}$. Deep snow cover acts as an insulating layer, whereas shallow and variable snow cover leads to lower soil temperatures and a higher FFTC during the winter ${ }^{29}$. In our study, FFTC was the principal factor determining lignin degradation, which was higher in the environments with greater FFTC, i.e., 

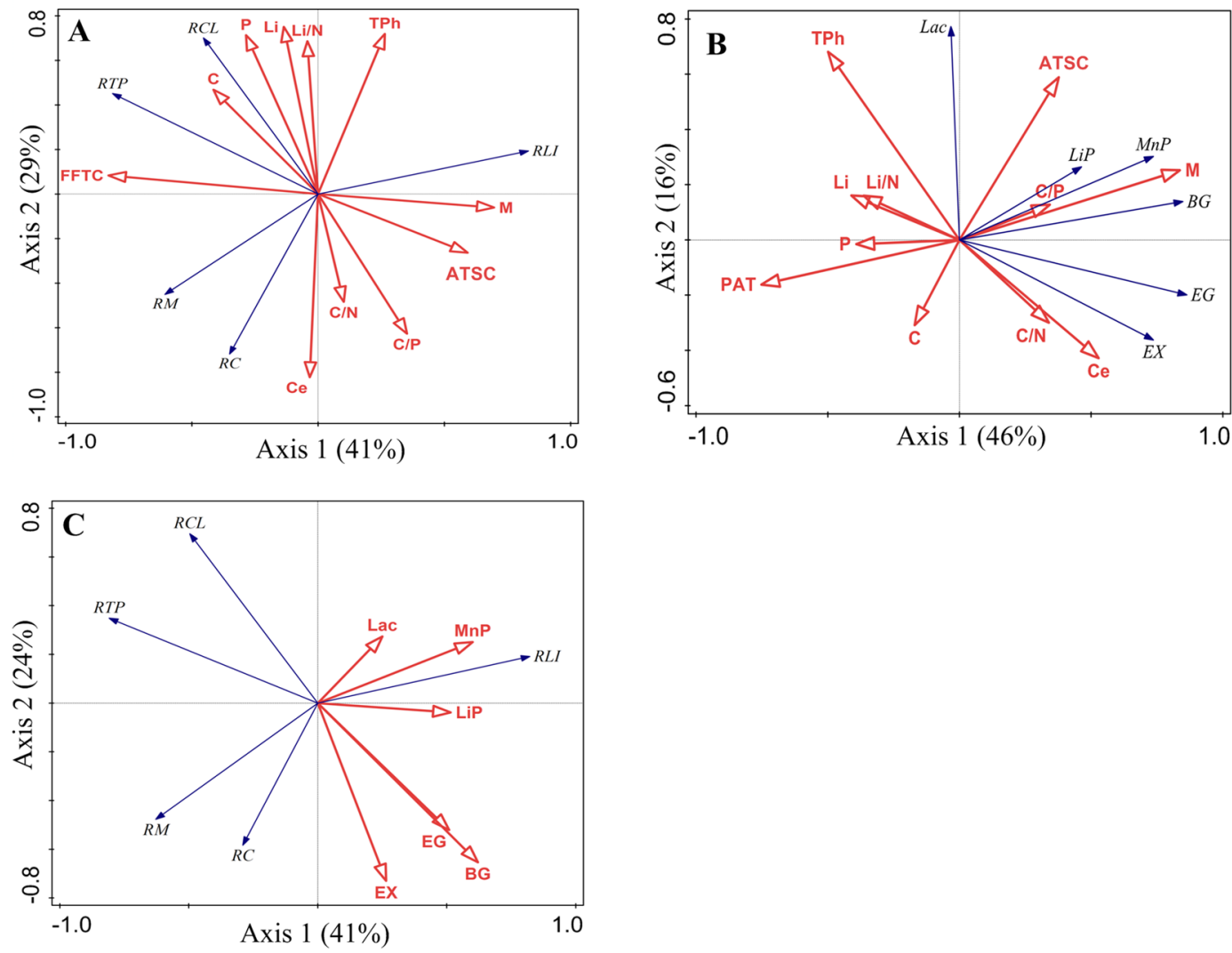

Figure 6. Redundancy analysis of the mass loss, element release (\%) (A,C) and enzyme activities (B) of leaf litters. C, carbon concentration; $\mathrm{N}$, nitrogen concentration; $\mathrm{P}$, phosphorus concentration; Ce, cellulose concentration; Li, lignin concentration; $\mathrm{TPh}$, total phenol concentration; $\mathrm{M}$, moisture content of the litter; AT, average temperature; FFTC, frequency of the freeze-thaw cycle; PAT, positive accumulated temperature; NAT, negative accumulated temperature; ATSC, average thickness of the snow cover; ML, mass loss (\%); CR, carbon release (\%); CED, cellulose degradation (\%); LID, lignin degradation (\%); TPL, total phenol loss (\%); Lac, laccase; $\mathrm{MnP}$, manganese peroxidase; LiP, lignin peroxidase; $\mathrm{EG}$, endo-1,4- $\beta$-glucanase; $\beta \mathrm{G}, 1,4$ - $\beta$-glucosidase; EX, endo-1,4- $\beta$-xylanase.

the tree line or alpine meadow. These results support the view that the decomposition of recalcitrant components is facilitated by freezing events ${ }^{48,49}$. On the one hand, freezing events can promote the physical breakdown of organic matter, on the other hand, thawing events can intensify the leaching of soluble compounds in litter ${ }^{48,49}$. The total phenol loss from all three litter types in the coniferous forest was higher than in the tree line or alpine meadow and was associated with higher moisture content and ATSC. This can be explained by the rapid loss of the labile portion such as polyphenols through hydraulic leaching ${ }^{50}$. It has been shown that lignin usually exhibits accumulation, whereas cellulose may either lose or accumulate in the early period of decomposition ${ }^{2}$. In the present study, the cellulose of SP in the alpine forest-tundra ecotone and the lignin of the three litter types in the coniferous forest exhibited absolute accumulation, which is consistent with the observation in Berg and Mcclaugherty ${ }^{2}$ and Li et al. ${ }^{51}$. The acid detergent lignin which was determined by the Van Soest method is composed of both lignin and other acid resistant compound $s^{33,52}$. Hence, one possible explanation for the absolute increase in lignin might be an increase in lignin-like compounds originating from microbial products ${ }^{51,53}$. The effects of litter affinity, which has been termed home-field advantage (HFA, decomposition is accelerated in its home environment), have been reported in previous studies ${ }^{54,55}$, but in our study, the three litter types did not exhibit HFA, possibly due to the selection of different plant functional types and marked variations in the microclimatic conditions along the ecotone.

Our results clearly demonstrated that most ligninolytic and cellulolytic enzyme activities were affected by vegetation type and litter type. Moreover, the effects of microclimatic factors were greater than those of litter quality on the variation in enzyme activities at the early decomposition stage. In particular, moisture content was the strongest explanatory factor for the variation in enzyme activities. It has been demonstrated that fungi are the main producers of extracellular enzymes associated with the degradation of lignin and cellulose $\mathrm{e}^{56,57}$, particularly during the initial decomposition stages ${ }^{58}$. Soil moisture can directly promote enzyme-catalysed processes ${ }^{59,60}$ as well as indirectly alter enzyme activity by influencing the microbial biomass ${ }^{60}$; for instance, positive correlations have been observed between soil moisture content and fungal biomass 9 . Higher enzyme activities in the litter were correlated with higher fungal biomass; presumably, the fungi were the main source of the enzymes ${ }^{22}$. Air temperature decreases with elevation ${ }^{61}$; however, there was a temperature inversion phenomenon along the forest-tundra ecotone ${ }^{31}$, with the average decomposition temperature of the alpine meadow being higher than 


\begin{tabular}{|c|c|c|c|c|}
\hline \multirow[b]{2}{*}{ Variable } & \multirow{2}{*}{$\begin{array}{l}\text { Simple term effects } \\
\text { (\% explained) }\end{array}$} & \multirow{2}{*}{$\begin{array}{l}\text { Conditional term } \\
\text { effects (\% explained) }\end{array}$} & \multicolumn{2}{|c|}{$\begin{array}{l}\text { Correlation } \\
\text { coefficient with axis }\end{array}$} \\
\hline & & & Axis 1 & Axis 2 \\
\hline \multicolumn{5}{|c|}{ Litter quality } \\
\hline \multicolumn{5}{|c|}{ (explained $28 \%{ }^{* *}$ of the total variation) } \\
\hline $\mathrm{C}$ & $16^{*}$ & ns & -0.395 & 0.429 \\
\hline $\mathrm{N}$ & $13^{*}$ & ns & -0.159 & 0.534 \\
\hline $\mathrm{P}$ & $20^{* *}$ & ns & -0.272 & 0.653 \\
\hline $\mathrm{C} / \mathrm{N}$ & ns & ns & 0.097 & -0.443 \\
\hline $\mathrm{C} / \mathrm{P}$ & $19^{* *}$ & $14^{* *}$ & 0.336 & -0.574 \\
\hline $\mathrm{Ce}$ & $20^{* *}$ & $20^{* *}$ & -0.031 & -0.753 \\
\hline $\mathrm{Li}$ & $18^{* *}$ & ns & -0.129 & 0.688 \\
\hline $\mathrm{Li} / \mathrm{N}$ & $14^{*}$ & $\mathrm{~ns}$ & -0.040 & 0.629 \\
\hline $\mathrm{TPh}$ & $18^{* *}$ & ns & 0.252 & 0.659 \\
\hline \multicolumn{5}{|c|}{ Environmental factors } \\
\hline \multicolumn{5}{|c|}{ (explained $53 \%^{* *}$ of the total variation) } \\
\hline $\mathrm{M}$ & $22^{* *}$ & $6^{* *}$ & 0.664 & -0.056 \\
\hline AT & $29^{* *}$ & ns & -0.784 & -0.028 \\
\hline FFTC & $30^{* *}$ & $30^{* *}$ & -0.790 & 0.076 \\
\hline PAT & $23^{* *}$ & ns & -0.682 & -0.136 \\
\hline NAT & $29^{* *}$ & ns & -0.786 & 0.084 \\
\hline ATSC & $17^{* *}$ & $5^{* *}$ & 0.565 & -0.242 \\
\hline
\end{tabular}

Table 4. Summary statistics of the redundancy analysis describing the amount of variation (\%) in mass loss and element release of leaf litter explained by litter quality and environmental factors and the correlation coefficients between the variables and the axis. Significance of the effects: ns, not significant; $* \mathrm{P}<0.05$; $* * \mathrm{P}<0.01$. Simple term effects show the amount of variation explained by each variable (equivalent to the explanatory power of each individual variable using constrained ordination analysis). Conditional term effects show the increase in the explanatory power after adding a new variable based on the order of explanation. C, carbon concentration; $\mathrm{N}$, nitrogen concentration; $\mathrm{P}$, phosphorus concentration; Ce, cellulose concentration; Li, lignin concentration; $\mathrm{TPh}$, total phenol concentration; M, moisture content of the litter; AT, average daily temperature; FFTC, frequency of the freeze-thaw cycle; PAT, positive accumulated temperature; NAT, negative accumulated temperature; ATSC, average thickness of the snow cover; $(n=27)$.

that of the coniferous forest despite the alpine meadow's higher elevation. Furthermore, although a previous study predicted that enzyme activity should substantially increase with increasing temperature ${ }^{9}$, the lignocellulolytic enzyme activities in this study did not increase with temperature. This result might be due to the influence of other variables (such as moisture, solar radiation, and snow cover) that altered the effect of temperature on enzyme activity during litter decomposition.

Both litter type and quality can strongly influence extracellular enzyme activity ${ }^{10,62}$. Differences in initial litter quality, such as the relative proportions of lignin and cellulose, can lead to differences in enzyme activity ${ }^{11}$, and the initial cellulose concentration of DS was higher than that of SP and AO (Table 2), which is consistent with the highest cellulolytic enzyme (EG, $\beta$ G, and EX) activities being found for DS. In our study, cellulolytic enzyme activities were generally related to the cellulose concentration (Fig. 6B and Table 5), which is consistent with the results of Kanazawa and Miyashita ${ }^{63}$, Linkins et al. ${ }^{64}$, and Allison and Vitousek ${ }^{65}$. Interestingly, the ligninolytic enzyme activities rather than the cellulolytic enzyme activities were positively correlated with total phenols at the early decomposition stage in our study. This result is consistent with the opposing responses of the oxidative enzyme and hydrolytic enzyme activities to litter quality (e.g., soluble phenolic compounds, plant litter lignin content and $\mathrm{N}$ availability) as identified through principal components and multidimensional scaling analyses of soil and litter enzyme activity ${ }^{66}$. In our study, the correlation between extracellular enzyme activities and the $\mathrm{C}$ and $\mathrm{N}$ concentrations were not significant, which is inconsistent with the results reported by Schnecker et al. ${ }^{67}$.

The observed ligninolytic and cellulolytic enzyme activities partially accounted for the variation in overall litter decomposition, which suggested that microbial activity played a vital role during litter decomposition in the snow-covered season $30,68,69$. In our study, the explanatory power of cellulolytic enzyme activities was higher than that of ligninolytic enzyme activities in terms of the variation in litter decomposition. This result could be explained by cellulose being preferentially degraded to yield glucose during the early stages of plant litter decomposition $^{1,5}$. The final step in cellulose depolymerisation, namely, the hydrolysis of cellobiose to glucose, is catalysed by $\beta G$, which is the most commonly measured cellulolytic enzyme in ecological studies ${ }^{5}$. Among enzyme variables, the activity of $\beta \mathrm{G}$ was the factor explaining most of the variation in the overall litter decomposition (Fig. 6C and Table 6).

In summary, the overall litter decomposition and cellulolytic and ligninolytic enzyme activities were significantly influenced by microclimate variables and litter type during the early litter decomposition stage. Microclimatic factors were found to be stronger predictors than litter quality of the variations in litter decomposition and lignocellulolytic activity. Interestingly, FFTC and moisture were the predominant microclimate factors. 


\begin{tabular}{|c|c|c|c|c|}
\hline \multirow[b]{2}{*}{ Variable } & \multirow{2}{*}{$\begin{array}{l}\text { Simple term effects } \\
\text { (\% explained) }\end{array}$} & \multirow{2}{*}{$\begin{array}{l}\text { Conditional term } \\
\text { effects (\% explained) }\end{array}$} & \multicolumn{2}{|c|}{$\begin{array}{l}\text { Correlation } \\
\text { coefficient with axis }\end{array}$} \\
\hline & & & Axis 1 & Axis 2 \\
\hline \multicolumn{5}{|c|}{ Litter quality } \\
\hline \multicolumn{5}{|c|}{ (explained $17 \% * *$ of the total variation) } \\
\hline $\mathrm{C}$ & ns & ns & -0.153 & -0.256 \\
\hline $\mathrm{N}$ & ns & ns & -0.321 & 0.186 \\
\hline $\mathrm{P}$ & ns & ns & -0.353 & -0.013 \\
\hline $\mathrm{C} / \mathrm{N}$ & ns & ns & 0.306 & -0.249 \\
\hline $\mathrm{C} / \mathrm{P}$ & ns & $7 * *$ & 0.310 & 0.106 \\
\hline $\mathrm{Ce}$ & $17 * *$ & ns & 0.477 & -0.355 \\
\hline $\mathrm{Li}$ & $10 * *$ & ns & -0.371 & 0.133 \\
\hline $\mathrm{Li} / \mathrm{N}$ & ns & ns & -0.328 & 0.133 \\
\hline $\mathrm{TPh}$ & $19 * *$ & $17 * *$ & -0.450 & 0.565 \\
\hline \multicolumn{5}{|c|}{ Environmental factors } \\
\hline \multicolumn{5}{|c|}{ (explained $48 \% * *$ of the total variation) } \\
\hline $\mathrm{M}$ & $34 * *$ & $34^{* *}$ & 0.755 & 0.209 \\
\hline AT & $30 * *$ & ns & -0.700 & -0.290 \\
\hline F FTC & $27 * *$ & ns & -0.64 & -0.405 \\
\hline PAT & $27 * *$ & ns & -0.678 & -0.134 \\
\hline NAT & $27 * *$ & ns & -0.632 & -0.412 \\
\hline ATSC & $13 * *$ & $5^{*}$ & 0.340 & 0.489 \\
\hline
\end{tabular}

Table 5. Summary statistics of the redundancy analysis describing the amount of the variation (\%) in enzyme activities explained by litter quality and environmental factors and the correlation coefficients between the variables and the axis. Significance of the effects: $\mathrm{ns}$, not significant; $* \mathrm{P}<0.05 ; * * \mathrm{P}<0.01$. Simple term effects show the amount of variation explained by each variable (equivalent to the explanatory power of each individual variable using constrained ordination analysis). Conditional term effects show the increase in explanatory power after adding a new variable based on the order of explanation. C, carbon concentration; N, nitrogen concentration; $\mathrm{P}$, phosphorus concentration; Ce, cellulose concentration; Li, lignin concentration; $\mathrm{TPh}$, total phenol concentration; M, moisture content of the litter; AT, average temperature; FFTC, frequency of the freezethaw cycle; PAT, positive accumulated temperature; NAT, negative accumulated temperature; ATSC, average thickness of the snow cover; $(n=27)$.

\begin{tabular}{|c|c|c|c|c|}
\hline \multirow[b]{2}{*}{ Variable } & \multirow{2}{*}{$\begin{array}{l}\text { Simple term effects } \\
\text { (\% explained) }\end{array}$} & \multirow{2}{*}{$\begin{array}{l}\text { Conditional term } \\
\text { effects (\% explained) }\end{array}$} & \multicolumn{2}{|c|}{$\begin{array}{l}\text { Correlation } \\
\text { coefficient with axis }\end{array}$} \\
\hline & & & Axis 1 & Axis 2 \\
\hline \multicolumn{5}{|c|}{ Ligninolytic enzyme activities } \\
\hline \multicolumn{5}{|c|}{ (explained $29 \% * *$ of the total variation) } \\
\hline $\mathrm{Lac}$ & ns & $6^{*}$ & 0.239 & 0.231 \\
\hline $\mathrm{MnP}$ & $20 * *$ & $19 * *$ & 0.572 & 0.212 \\
\hline $\mathrm{LiP}$ & $11^{*}$ & $10 * *$ & 0.491 & -0.032 \\
\hline \multicolumn{5}{|c|}{ Cellulolytic enzyme activities } \\
\hline \multicolumn{5}{|c|}{ (explained $48 \% * *$ of the total variation) } \\
\hline EG & $18^{* * *}$ & $6^{*}$ & 0.485 & -0.440 \\
\hline$\beta G$ & $27^{* * *}$ & $27 * *$ & 0.592 & -0.552 \\
\hline $\mathrm{EX}$ & $16^{* * *}$ & $9 *$ & 0.253 & -0.617 \\
\hline
\end{tabular}

Table 6. Summary statistics of the redundancy analysis describing the amount of the variation (\%) in the mass loss and element release of leaf litter explained by enzyme activities and the correlation coefficients between the variables and the axis. Significance of the effects: $\mathrm{ns}$, not significant; $* \mathrm{P}<0.05$; $* * \mathrm{P}<0.01$. Simple term effects show the amount of variation explained by each variable (equivalent to the explanatory power of each individual variable using constrained ordination analysis). Conditional term effects show the increase in the explanatory power after adding a new variable based on the order of explanation. Lac, laccase; MnP, manganese peroxidase; LiP, lignin peroxidase; EG, endo-1,4- $\beta$-glucanase; $\beta$ G, 1,4- $\beta$-glucosidase; EX, endo-1,4- $\beta$-xylanase; $(n=27)$.

In addition, the explanatory power of cellulolytic enzyme activities was higher than that of ligninolytic enzyme activities at the early stage of litter decomposition. In contrast to the pattern observed for lignin degradation, the total phenol loss, $\mathrm{MnP}$ and cellulolytic enzyme activities of the three litter species were higher in the coniferous forest than at the treeline or in the alpine meadow. The higher cellulose degradation was consistent with the higher cellulose concentration and cellulolytic enzyme activities in the litter. Therefore, under climate change, the direction and magnitude of changes in microclimatic factors and litter quality warrant study in alpine ecosystems. 


\section{Data Availability}

The datasets generated and/or analysed in the current study are available from the corresponding author upon reasonable request.

\section{References}

1. Couteaux, M. et al. Litter decomposition, climate and liter quality. Trends Ecol. Evol. 10, 63-66 (1995).

2. Berg, B. \& Mcclaugherty, C. Plant litter: decomposition, humus formation, carbon sequestration (Springer, 2008).

3. Horner, J. D. et al. The role of carbon-based plant secondary metabolites in decomposition in terrestrial ecosystems. Am. Nat. 132, 869-883 (1988).

4. Goyal, A., Ghosh, B. \& Eveleigh, D. Characteristics of fungal cellulases. Bioresource Technol. 36, 37-50 (1991).

5. Sinsabaugh, R. L. \& Shah, J. J. F. Ecoenzymatic stoichiometry of recalcitrant organic matter decomposition: the growth rate hypothesis in reverse. Biogeochemistry 102, 31-43 (2011).

6. Kirk, T. K. \& Farrell, R. L. Enzymatic “combustion”: the microbial degradation of lignin. Annu. Rev. Microbiol. 41, 465 (1987).

7. Sinsabaugh, R. L. et al. Stoichiometry of soil enzyme activity at global scale. Ecol. Lett. 11, 1252-1264 (2008).

8. Sinsabaugh, R. L. et al. Allocation of extracellular enzymatic activity in relation to litter composition, $\mathrm{N}$ deposition, and mass loss. Biogeochemistry 60, 1-24 (2002).

9. Baldrian, P. et al. Responses of the extracellular enzyme activities in hardwood forest to soil temperature and seasonality and the potential effects of climate change. Soil Biol. Biochem. 56, 60-68 (2013).

10. Allison, S. D. \& Vitousek, P. M. Extracellular enzyme activities and carbon chemistry as drivers of tropical plant litter decomposition. Biotropica 36, 285-296 (2004).

11. Sinsabaugh, R. L., Antibus, R. K. \& Linkins, A. E. An enzymic approach to the analysis of microbial activity during plant litter decomposition. Agr. Ecosyst. Environ. 34, 43-54 (1991).

12. Waldrop, M. P. \& Firestone, M. K. Response of microbial community composition and function to soil climate change. Microb. Ecol. 52, 716-724 (2006).

13. Bharti, R. R., Adhikari, B. S. \& Rawat, G. S. Assessing vegetation changes in timberline ecotone of Nanda Devi National Park, Uttarakhand. Int. J. Appl. Earth Obs. 18, 472-479 (2012).

14. McDaniel, M. D., Kaye, J. P. \& Kaye, M. W. Increased temperature and precipitation had limited effects on soil extracellular enzyme activities in a post-harvest forest. Soil Biol. Biochem. 56, 90-98 (2013).

15. A'Bear, A. D., Jones, T. H., Kandeler, E. \& Boddy, L. Interactive effects of temperature and soil moisture on fungal-mediated wood decomposition and extracellular enzyme activity. Soil Biol. Biochem. 70, 151-158 (2012).

16. Gavazov, K. S. Dynamics of alpine plant litter decomposition in a changing climate. Plant Soil 337, 19-32 (2010).

17. Garamvölgyi, Á. \& Hufnagel, L. Impacts of climate change on vegetation distribution no. 1 climate change induced vegetation shifts in the palearctic region. Appl. Ecol. Env. Res. 11, 79-122 (2013).

18. Cannone, N., Sgorbati, S. \& Guglielmin, M. Unexpected impacts of climate change on alpine vegetation. Front. Ecol. Environ. 5, 360-364 (2007).

19. Zhang, Y. \& Welker, J. M. Tibetan alpine tundra responses to simulated changes in climate: aboveground biomass and community responses. Arctic Alpine Res. 28, 203-209 (1996).

20. Berger, T. W. et al. Decomposition of beech (Fagus sylvatica) and pine (Pinus nigra) litter along an Alpine elevation gradient: decay and nutrient release. Geoderma 251, 92-104 (2015).

21. Duboc, O. et al. Decomposition of European beech and black pine foliar litter along an Alpine elevation gradient: mass loss and molecular characteristics. Geoderma 189, 522-531 (2012).

22. Djukic, I. et al. Microbial community composition and activity in different Alpine vegetation zones. Soil Biol. Biochem. 42, 155-161 (2010).

23. Margesin, R. et al. Litter decomposition at two forest sites in the Italian Alps: a field study. Arct. Antarct. Alp. Res. 48, 127-138 (2016).

24. Margesin, R. et al. Microbial communities and activities in alpine and subalpine soils. FEMS Microbiol. Ecol. 67, 208-218 (2009).

25. Schinner, F. Soil microbial activities and litter decomposition related to altitude. Plant Soil 65, 87-94 (1982).

26. Xu, Z. et al. The variations in soil microbial communities, enzyme activities and their relationships with soil organic matter decomposition along the northern slope of Changbai Mountain. Appl. Soil Ecol. 86, 19-29 (2015).

27. Alessi, A. M. et al. Revealing the insoluble metasecretome of lignocellulose-degrading microbial communities. Sci. Rep. 7, 2356 (2017).

28. Körner, C. \& Paulsen, J. A world-wide study of high altitude treeline temperatures. J. Biogeogr. 31, 713-732 (2004).

29. Baptist, F., Yoccoz, N. G. \& Choler, P. Direct and indirect control by snow cover over decomposition in alpine tundra along a snowmelt gradient. Plant Soil 328, 397-410 (2010).

30. Wu, F. et al. Litter decomposition in two subalpine forests during the freeze-thaw season. Acta Oecologica 36, 135-140 (2010).

31. Liu, Y. et al. Changes in foliar litter decomposition of woody plants with elevation across an alpine forest-tundra ecotone in eastern Tibet Plateau. Plant Ecol. 217, 495-504 (2016).

32. Zhu, J. et al. Decomposition of litter varies with freeze-thaw stages and altitudes in subalpine/alpine forests of southwest China. Scand. J. Forest Res. 27, 586-596 (2012).

33. Lu, R. Soil and agro-chemical analytical methods (China Agricultural Science and Technology Press, 1999).

34. Soest, P.J. \& Robertson, J.B. Standarisation of analytical methodology for feeds in Systems of analysis for evaluating fibrous feeds 47-60 (1980).

35. He, W. et al. Lignin degradation in foliar litter of two shrub species from the gap center to the closed canopy in an Alpine fir forest. Ecosystems 19, 115-128 (2016).

36. Makkar, H. P., Siddhuraju, P. \& Becker, K. Plant secondary metabolites (Humana Press, 2007).

37. Criquet, S., Tagger, S., Vogt, G., Iacazio, G. \& Le Petit, J. Laccase activity of forest litter. Soil Biol. Biochem. 31, 1239-1244 (1999).

38. Fujii, K., Uemura, M., Hayakawa, C., Funakawa, S. \& Kosaki, T. Environmental control of lignin peroxidase, manganese peroxidase, and laccase activities in forest floor layers in humid Asia. Soil Biol. Biochem. 57, 109-115 (2013).

39. Arora, D. S., Chander, M. \& Gill, P. K. Involvement of lignin peroxidase, manganese peroxidase and laccase in degradation and selective ligninolysis of wheat straw. Int. Biodeter. Biodegr. 50, 115-120 (2002).

40. Criquet, S. Measurement and characterization of cellulase activity in sclerophyllous forest litter. J. Microbiol. Meth. 50, 165-173 (2002).

41. Valášková, V. et al. Production of lignocellulose-degrading enzymes and degradation of leaf litter by saprotrophic basidiomycetes isolated from a Quercus petraea forest. Soil Biol. Biochem. 39, 2651-2660 (2007).

42. Vendula, V. \& Petr, B. Degradation of cellulose and hemicelluloses by the brown rot fungus Piptoporus betulinus-production of extracellular enzymes and characterization of the major cellulases. Microbiology 152, 3613-3622 (2006).

43. Miller, G. L. Use of dinitrosalicylic acid reagent tor determination oi reducing sugar. Anal. Chem. 31, 426-428 (1959).

44. Ni, X. et al. Forest gaps slow the sequestration of soil organic matter: a humification experiment with six foliar litters in an alpine forest. Sci. Rep. 6, 19744 (2016).

45. Konestabo, H. S., Michelsen, A. \& Holmstrup, M. Responses of springtail and mite populations to prolonged periods of soil freezethaw cycles in a sub-arctic ecosystem. Appl. Soil. Ecol. 36, 136-146 (2007). 
46. Drewnik, M. The effect of environmental conditions on the decomposition rate of cellulose in mountain soils. Geoderma 132, 116-130 (2006)

47. Seastedt, T. R., Walker, M. D., Bryant, D. M., Bowman, W. D. \& Seastedt, T. R. Controls on decomposition processes in alpine tundra in Structure and function of an alpine ecosystem: Niwot Ridge, Colorado (eds. Bowman, W. D. \& Seastedt, T. R.) 222-236 (Oxford University Press, 2001).

48. Schimel, J. P. \& Clein, J. S. Microbial response to freeze-thaw cycles in tundra and taiga soils. Soil Biol. Biochem. 28, 1061-1066 (1996).

49. Groffman, P. M. et al. Effects of mild winter freezing on soil nitrogen and carbon dynamics in a northern hardwood forest. Biogeochemistry 56, 191-213 (2001).

50. García Palacios, P. et al. Temporal dynamics of biotic and abiotic drivers of litter decomposition. Ecol. Lett. 19, 554-563 (2016).

51. Li, H. et al. Effects of forest gaps on litter lignin and cellulose dynamics vary seasonally in an alpine forest. Forests $7,27(2016)$.

52. Ni, X. et al. Accelerated foliar litter humification in forest gaps: Dual feedbacks of carbon sequestration during winter and the growing season in an alpine forest. Geoderma 241, 136-144 (2015).

53. Brandt, L. A., King, J. Y., Hobbie, S. E., Milchunas, D. G. \& Sinsabaugh, R. L. The role of photodegradation in surface litter decomposition across a grassland ecosystem precipitation gradient. Ecosystems 13, 765-781 (2010).

54. Austin, A. T. et al. There's no place like home? An exploration of the mechanisms behind plant litter-decomposer affinity in terrestrial ecosystems. New Phytol. 204, 307-314 (2014).

55. Ayres, E. et al. Home-field advantage accelerates leaf litter decomposition in forests. Soil Biol. Biochem. 41, 606-610 (2009).

56. Romaní, A. M. et al. Interactions of bacteria and fungi on decomposing litter: differential extracellular enzyme activities. Ecology 87, 2559 (2006).

57. Schneider, T. Who is who in litter decomposition: metaproteomics reveals major microbial players and their biogeochemical functions. ISME J. 6, 1749 (2012).

58. Snajdr, J. et al. Saprotrophic basidiomycete mycelia and their interspecific interactions affect the spatial distribution of extracellular enzymes in soil. FEMS Microbiol. Ecol. 78, 80-90 (2011).

59. Andersson, M., Kjoller, A. \& Struwe, S. Microbial enzyme activities in leaf litter, humus and mineral soil layers of European forests. Soil Biol. Biochem. 36, 1527-1537 (2004).

60. Baldrian, P., Merhautová, V., Cajthaml, T., Petránková, M. \& Šnajdr, J. Small-scale distribution of extracellular enzymes, fungal, and bacterial biomass in Quercus petraea forest topsoil. Biol. Fert. Soils 46, 717-726 (2010).

61. Withington, C. L. \& Sanford, R. L. Jr. Decomposition rates of buried substrates increase with altitude in the forest-alpine tundra ecotone. Soil Biol Biochem. 39, 68-75 (2007).

62. Waring, B. G. Exploring relationships between enzyme activities and leaf litter decomposition in a wet tropical forest. Chem. Ecol. 64, 89-95 (2013)

63. Kanazawa, S. \& Miyashita, K. Cellulase activity in forest soils. Soil Sci. Plant Nutr. 33, 399-406 (1987).

64. Linkins, A. E., Sinsabaugh, R. L., Mcclaugherty, C. A. \& Melills, J. M. Cellulase activity on decomposing leaf litter in microcosms. Plant Soil 123, 17-25 (1990).

65. Allison, S. D. \& Vitousek, P. M. Responses of extracellular enzymes to simple and complex nutrient inputs. Soil Biol. Biochem. 37, 937-944 (2005)

66. Sinsabaugh, R. L. Phenol oxidase, peroxidase and organic matter dynamics of soil. Soil Biol. Biochem. 42, 391-404 (2010).

67. Schnecker, J. et al. Effects of soil organic matter properties and microbial community composition on enzyme activities in cryoturbated Arctic soils. PLoS One 9, e94076 (2014).

68. Brooks, P. D. et al. Carbon limitation of soil respiration under winter snowpacks: potential feedbacks between growing season and winter carbon fluxes. Global Change Biol. 11, 231-238 (2005).

69. Uchida, M. et al. Microbial activity and litter decomposition under snow cover in a cool-temperate broad-leaved deciduous forest. Agr. Forest Meteorol. 134, 102-109 (2005).

\section{Acknowledgements}

We are grateful to two anonymous reviewers for their thoughtful and constructive comments, and we thank Tuowei Ji, Jianping Li, Xiaoyan Song, and Chao Deng for their help with the field sampling and laboratory analysis. This work was financially supported by projects from the National Natural Science Foundation of China (31200345, 31570605), the Ministry of Education Doctoral Fund Project (20115103120003), and National Key Technologies R\&D of China (No. 2011BAC09B05).

\section{Author Contributions}

Yang Liu and Wanqin Yang designed the study. Yamei Chen, Runlian He and Changchun Deng performed the research and analysed the data. Jian Zhang proposed the structure of the paper, and Yamei Chen wrote the paper.

\section{Additional Information}

Competing Interests: The authors declare no competing interests.

Publisher's note: Springer Nature remains neutral with regard to jurisdictional claims in published maps and institutional affiliations.

(c) (i) Open Access This article is licensed under a Creative Commons Attribution 4.0 International

License, which permits use, sharing, adaptation, distribution and reproduction in any medium or format, as long as you give appropriate credit to the original author(s) and the source, provide a link to the Creative Commons license, and indicate if changes were made. The images or other third party material in this article are included in the article's Creative Commons license, unless indicated otherwise in a credit line to the material. If material is not included in the article's Creative Commons license and your intended use is not permitted by statutory regulation or exceeds the permitted use, you will need to obtain permission directly from the copyright holder. To view a copy of this license, visit http://creativecommons.org/licenses/by/4.0/.

(C) The Author(s) 2018 